\title{
Pengaruh Tingkat Utang, Ukuran Perusahaan dan Kepemilikan Manajerial pada Persistensi Laba
}

\author{
Ni Nyoman Dita Arisandi ${ }^{1}$ \\ Ida Bagus Putra Astika ${ }^{2}$ \\ ${ }^{1,2}$ Fakultas Ekonomi dan Bisnis Universitas Udayana (Unud), Bali, Indonesia \\ e-mail: ditaarisandi19@gmail.com
}

\begin{abstract}
ABSTRAK
Tujuan penelitian ini adalah untuk mendapatkan bukti empiris pengaruh tingkat utang, ukuran perusahaan, dan kepemilikan manajerial pada persistensi laba. Penelitian ini dilakukan di BEI dengan memilih sampel perusahaan property dan real estate pada tahun 2013 sampai 2016. Jumlah sampel yang diambil sebanyak 11 perusahaan dengan metode non probability sampling yaitu dengan cara purposive sampling. Teknik analisis yang digunakan adalah regresi linear berganda. Selain itu, penelitian ini juga menggunakan analisis regresi sederhana untuk mengukur persistensi laba serta melihat apakah terdapat persistensi laba pada data yang digunakan dalam penelitian ini. Berdasarkan hasil analisis ditemukan bahwa tingkat utang dan kepemilikan manajerial tidak berpengaruh pada persistensi laba. Ukuran perusahaan berpengaruh positif pada persistensi laba. Perusahaan yang berukuran besar memiliki kinerja dan sistem yang baik untuk mengendalikan, mengelola, mengatur semua aktiva yang dimiliki oleh perusahaan. Pengendalian, pengelolaan dan pengaturan aset perusahaan yang efektif dan efisien ini berpotensi untuk mendatangkan laba yang lebih maksimal.
\end{abstract}

Kata kunci: Tingkat utang, ukuran perusahaan, kepemilikan manajerial, persistensi laba

\begin{abstract}
The purpose of this study is to obtain empirical evidence of the effect of debt levels, firm size, and managerial ownership on earnings persistence. This research was conducted at the IDX by selecting samples of property and real estate companies in 2013 to 2016. The number of samples taken was 11 companies with non probability sampling method, namely by purposive sampling. The analysis technique used is multiple linear regression. Based on the results of the analysis it was found that the level of debt and managerial ownership had no effect on earnings persistence. Company size has a positive effect on earnings persistence. Large companies have good performance and systems to control, manage, manage all assets owned by the company. This effective and efficient control, management and regulation of company assets has the potential to bring maximum profit.

Keywords: Level of debt, firm size, managerial ownership, earnings persistence
\end{abstract}

\section{PENDAHULUAN}

Kondisi perekonomian global mengalami tekanan akibat krisis yang menghadapkan perekonomian Indonesia pada sejumlah tantangan yang tidak ringan. Nilai tukar rupiah terhadap dolar Amerika Serikat masih belum bisa 
bangkit dari keterpurukan. Kondisi ini menyebabkan banyaknya sektor industri di Indonesia yang mengalami penurunan pertumbuhan dan perkembangan. Sektor industri yang paling rentan terkena imbas anjloknya mata uang rupiah adalah sektor industri property dan real estate (Hartomo, 2018). Perusahaan property dan real estate merupakan perusahaan yang bergerak di bidang pengembangan bangunan seperti perumahan, apartemen, hotel, tempat wisata, dan lain-lain. Perkembangan perusahaan property dan real estate dikaitkan dengan pesatnya laju pertumbuhan penduduk di Indonesia namun kurang diimbangi dengan sarana tempat tinggal yang memadai, sehingga sektor ini dapat menjadi lahan bisnis yang potensial sebagai tempat investasi yang dapat memberikan keuntungan yang tinggi.

Ketua Umum Dewan Pengurus Pusat Persatuan Perusahaan Real Estate Indonesia Soelaeman Soemawinata menyatakan bahwa pelemahan rupiah akan berdampak buruk bagi sektor property. Pasalnya,mayoritas barang konstruksi yang digunakan untuk pembangunan berasal dari impor, dengan melemahnya nilai tukar rupiah membuat harga barang konstruksi yang berasal dari impor tersebut meningkat. Hal tersebut mengakibatkan semakin melambungnya harga property sehinggadaya beli masyarakatuntuk membeli property semakin lesu. Tahun 2009 sektor property menjadi primadona dengan pertumbuhan pembangunan yang signifikan khususnya di Jabodetabek. Peningkatan ini juga kemudian mulai terjadi di kota-kota lain (Dewan Pengurus Pusat Persatuan Perusahaan Real Estate Indonesia, 2018). Namun, sejak tahun 2013 
perkembangan sektor property dan realestate melambat yang ditandai dengan penurunan laba bersih seperti yang ditunjukkan pada Gambar 1 berikut ini.

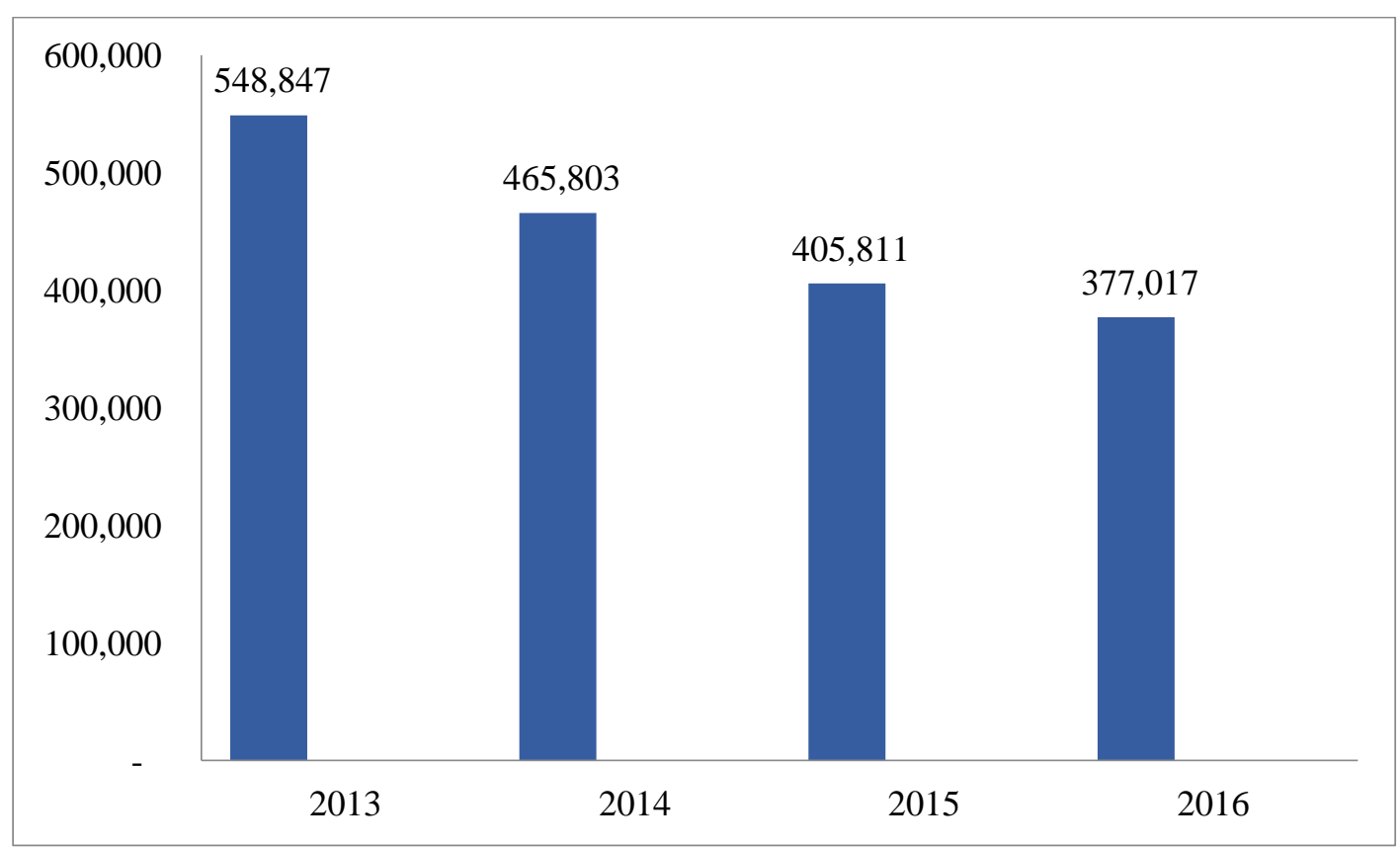

Gambar 1. Rata-rata Laba Bersih pada Perusahaan Sektor Industri Property dan Real Estate di BEI Periode 2013-2016 (dalam jutaan rupiah) Sumber: Data diolah, 2018

Gambar 1 menunjukkan bahwa perkembangan rata-rata laba bersih pada perusahaan sektor industri property dan real estate di BEI periode 2013-2016 yang terus mengalami penurunan. Rata-rata laba bersih perusahaan tersebut pada tahun 2013 sampai tahun 2016 secara berturut-turut sebesar Rp 548.847.334.189, Rp 465.803.336.129, Rp 405.810.456.820, dan Rp 377.016.968.361. Berdasarkan data tersebut terlihat bahwa penurunan laba bersih terbesar terjadi pada tahun 2014 yaitu sebesar Rp 83.043.998.060 atau 15,1\%

Salah satu informasi yang terdapat dalam laporan keuangan yang penting bagi pengguna laporan keuangan adalah informasi laba. Laba akuntansi dianggap sebagai sumber informasi dan elemen yang paling signifikan untuk mengevaluasi profitabilitas masa depan perusahaan yang dibutuhkan bagi para pemangku 
kepentingan, terutama investor (Moienadin et al., 2014). Tingkat pertumbuhan perusahaan dan hasil kegiatan operasi suatu perusahaan dapat dilihat dari besarnya laba yang diperoleh. Laba tidak hanya dapat digunakan untuk menilai dan mengevaluasi kinerja perusahaan, melainkan juga dapat dijadikan sebagai dasar pertimbangan dalam pengambilan keputusan untuk menentukan kebijakan perusahaan seperti pembagian dividen, penentuan investasi, dan pemberian bonus kepada karyawan (Sutisna, 2017). Investor cenderung memilih perusahaan yang memiliki laba yang meningkat secara stabil dalam menanamkan modalnya ke perusahaan, dikarenakan perusahaan yang memiliki laba yang besar akan memberikan dividen yang besar. Oleh karena itu,laba yang besar dan persisten perlu dipertahankan oleh perusahaan agar investor tertarik menanamkan modalnya (Martinez, 2015). Laba yang persisten adalah laba yang mempunyai kemampuan sebagai indikator laba periode mendatang (future earnings) yang dihasilkan oleh perusahaan secara berulang-ulang (repetitive) dalam jangka panjang (Hui et al., 2016). Pengertian persistensi laba pada prinsipnya dapat dipandang dalam dua sudut pandang. Pandangan pertama menyatakan bahwa persistensi laba berhubungan dengan kinerja keseluruhan perusahaan yang tergambarkan dalam laba perusahaan. Pandangan ini menyatakan bahwa laba yang persisten tinggi terefleksi pada laba yang dapat berkesinambungan (sustainable) untuk suatu periode yang lama. Pandangan kedua menyatakan persistensi laba berkaitan dengan kinerja harga saham pasar modal yang diwujudkan dalam bentuk imbal hasil, sehingga hubungan yang semakin kuat antara laba perusahaan dengan imbal hasil bagi investor dalam bentuk return saham menunjukkan persistensi laba yang 
tinggi (Sujana dkk., 2017). Hal tersebut membuat persistensi laba menjadi penting karena persistensi laba merupakan salah satu perhitungan acuan dalam pengambilan keputusan.

Fenomena menurunnya laba bersih perusahaan property dan real estate di atas menyebabkan persistensi laba pada sektor industri tersebut mulai dipertanyakan, karena laba dengan fluktuasi menurun curam dalam waktu yang singkat menunjukkan perusahaan tersebut tidak mampu untuk mempertahankan laba yang diperoleh saat ini maupun menjamin laba untuk masa depan (Zhou, 2016). Untuk menghasilkan laba yang persisten dapat dipengaruhi oleh beberapa faktor tertentu. Dalam penelitian ini faktor-faktor yang diduga dapat memengaruhi persistensi laba adalah tingkat utang, ukuran perusahaan, dan kepemilikan manajerial.

Faktor pertama yang diduga dapat memengaruhi persistensi laba adalah tingkat utang. Upaya perusahaan untuk memperoleh laba tidak terlepas dari sumber modal perusahaan untuk mengembangkan usaha demi menghasilkan laba yang maksimal. Salah satu sumber modal eksternal perusahaan adalah berupa pinjaman atau utang. Berdasarkan pecking order theory dipilihnya penerbitan obligasi (utang) lebih utama daripada penerbitan saham baru dikarenakan floatation cost (biaya penerbitan) untuk penerbitan obligasi lebih kecil dibandingkan penerbitan saham baru. Selain itu, utang dapat digunakan untuk mengurangi pajak penghasilan sehingga pajak pengasilan yang harus dibayar oleh perusahaan lebih kecil. Penghematan pajak tersebut dapat menjadikan laba yang diperoleh perusahaan menjadi lebih besar (Suwandika \& Astika, 2013). Tingkat 
Ni Nyoman Dita Arisandi dan Ida Bagus Putra Pastika. Pengaruh ...

utang adalah besarnya tingkat penggunaan utang dalam perusahaan. Besarnya tingkat utang cenderung akan mendorong perusahaan untuk meningkatkan persistensi laba dengan tujuan untuk mempertahankan kinerja perusahaan. Kinerja perusahaan yang baik diharapkan dapat membuat kreditor tetap memiliki kepercayaan terhadap perusahaan sehingga tetap memberikan pinjaman dana (Sulastri, 2014). Penelitian yang dilakukan oleh Putri dan Supadmi (2016) serta Anggraeni (2015) menghasilkan bahwa tingkat utang berpengaruh positif pada persistensi laba. Sedangkan penelitian yang dilakukan oleh Achyarsyah dan Purwanti (2018) menghasilkan bahwa tingkat utang berpengaruh negatif pada persistensi laba. Sementara itu penelitian yang dilakukan oleh Nuraini dan Purwanto (2014), Suwandika dan Astika (2013), menghasilkan bahwa tingkat utang tidak berpengaruh pada persistensi laba.

Faktor lain yang diduga dapat memengaruhi persistensi laba adalah ukuran perusahaan. Ukuran perusahaan merupakan skala besar kecilnya perusahaan. Perusahaan besar memiliki kestabilan dan operasi yang dapat diprediksi lebih baik, sehingga kesalahan estimasi yang ditimbulkan akan menjadi lebih kecil. Selain itu, perusahaan besar memiliki sumber daya yang besar untuk kegiatan usaha. Perusahaan besar dianggap memiliki prospek yang baik dalam jangka waktu yang relatif lama, selain itu juga mencerminkan bahwa perusahaan relatif lebih stabil dan lebih mampu menghasilkan laba dibanding perusahaan dengan total aktiva yang kecil. Para agen yang berada pada perusahaan besar akan selalu berupaya meningkatkan kinerjanya agar dinilai baik oleh prinsipal maupun calon investor, karena investor lebih tertarik pada perusahaan berukuran besar. Dengan 
besarnya ukuran perusahaan, maka kinerja agen harus sebaik mungkin untuk membuat laba perusahaan persisten. Persistensi laba perusahaan yang tinggi mengindikasikan hubungan yang semakin kuat antara laba perusahaan dengan imbal hasil bagi investor dalam bentuk return saham. Hal tersebutlah yang membuat investor lebih memiliki kepercayaan dan lebih tertarik pada perusahaan besar, karena perusahaan besar dianggap mampu untuk terus meningkatkan kinerja perusahaannya dengan berupaya meningkatkan persistensi laba perusahaan. Selain itu, pada perusahaan besar investor cenderung mengharapkan lebih banyak dividen dan di sisi lain kreditor juga mengharapkan bunga dan pokok pinjaman (Ali et al., 2015). Penelitian yang dilakukan oleh Dewi dan Putri (2015) serta Vichitsarawong (2015) menghasilkan bahwa ukuran perusahaan berpengaruh positif pada persistensi laba. Sedangkan penelitian yang dilakukan oleh Nuraeni, dkk. (2018) menghasilkan bahwa ukuran perusahaan berpengaruh negatif pada persistensi laba. Sementara itu penelitian yang dilakukan oleh Nurochman dan Solikhah (2015), Gschwandtner dan Cuaresma (2013) menghasilkan bahwa ukuran tidak berpengaruh pada persistensi laba.

Faktor lain yang juga diduga dapat memengaruhi persistensi laba selain tingkat utang dan ukuran perusahaan adalah kepemilikan manajerial. Kepemilikan manajerial merupakan besarnya kepemilikan saham oleh pihak manajemen perusahaan yang secara aktif ikut serta dalam pengambilan keputusan perusahaan. Kepemilikan manajerial merupakan salah satu cara untuk meminimalkan konflik keagenan (Jensen \& Meckling, 1996). Dengan adanya kepemilikan manajerial, agenakan termotivasi untuk bekerja lebih baik dalam meningkatkan kinerja 
perusahaan, karena agenmemiliki bagian atas laba yang dihasilkan oleh perusahaan (Tertius \& Christiawan, 2015). Manajer yang sekaligus merupakan pemegang saham akan berusaha meningkatkan persistensi laba perusahaan, karena dengan meningkatnya laba perusahaan maka dividen yang dibagikan kepada pemegang saham juga akan semakin meningkat. Sehingga kepentingan manajer (agen) dan pihak investor luar perusahaan akan sejalan, yaitu untuk sama-sama memperoleh dividen yang besar dari hasil investasinya. Penelitian yang dilakukan oleh Khafid (2012), serta Jumiati dan Ratnadi (2014) menghasilkan bahwa kepemilikan manajerial berpengaruh positif pada persistensi laba. Sedangkan penelitian yang dilakukan oleh Riswandi (2014) menghasilkan bahwa kepemilikan manajerial berpengaruh negatif pada persistensi laba. Sementara itu penelitian yang dilakukan oleh Putri dan Supadmi (2016) serta Nuraeni, dkk. (2018) menghasilkan bahwa kepemilikan manajerial tidak berpengaruh pada persistensi laba.

Persistensi laba menjadi bahasan yang sangat penting bagi para pengguna laporan keuangan khususnya investor dan kreditor sebagai bahan pertimbangan dalam pengambilan keputusan investasi dan pemberian kredit pada perusahaan. Persistensi laba adalah informasi akuntansi terkait dengan perkiraan pendapatan perusahaan masa depan dengan mengasumsikan bahwa laba yang dihasilkan secara terus-menerus lebih bermanfaat dalam mengevaluasi investasi (Kolozsvari, 2016). Persistensi laba dianggap sebagai karakteristik laba yang berkualitas pada akuntansi, berdasarkan atas data akuntansi tersebut dapat membantu investor untuk menilai laba masa depan perusahaan dan arus kasnya (Kordestani et al., 
2016). Laba yang persisten diperlukan oleh perusahaan untuk menunjukkan kinerja perusahaan yang baik dimata investor maupun kreditor. Penelitian terdahulu yang menguji mengenai persistensi laba telah beberapa kali dilakukan. Namun, hasil yang didapat dari beberapa penelitian tersebut tidak konsisten. Terdapat research gap yang signifikan antar hasil penelitian, dengan research gap yang signifikan antar hasil penelitian dan pentingnya persistensi laba dalam perusahaan di Indonesia, mendorong penelitian ini dilakukan.

Penelitian ini merupakan pengembangan dari penelitian yang dilakukan oleh Putri dan Supadmi (2016), perbedaannya adalah penelitian ini menggunakan sampel perusahaan property dan real estate sedangkan penelitian tersebut menggunakan sampel perusahaan manufaktur. Pemilihan sampel perusahaan property dan real estate dikarenakan bisnis property dan real estate memiliki prospek yang cerah dimasa depan dengan melihat potensi jumlah penduduk di Indonesia yang terus bertambah yang diikuti dengan bertambahnya kebutuhan manusia akan tempat tinggal, perkantoran, pusat perbelanjaan, taman hiburan, dan lain sebagainya. Namun, sejak tahun 2013 terjadi fenomena penurunan laba bersih pada perusahaan property dan real estate yang membuat persistensi laba pada sektor industri tersebut mulai dipertanyakan, hal tersebut membuat peneliti tertarik untuk melakukan penelitian di perusahaan property dan real estate. Selain itu, pada penelitian ini juga menambahkan variabel independen yaitu ukuran perusahaan. Alasan penambahan variabel ukuran perusahaan adalah karena ukuran perusahaan dapat mencerminkan baik tidaknya kinerja perusahaan dalam mengendalikan, mengelola, dan mengatur semua aktiva yang dimiliki oleh 
Ni Nyoman Dita Arisandi dan Ida Bagus Putra Pastika. Pengaruh ...

perusahaan. Pengendalian, pengelolaan dan pengaturan aset perusahaan yang efektif dan efisien berpotensi untuk mendatangkan laba yang lebih maksimal. Perusahaan besar yang telah mencapai tahap kedewasaan mencerminkan bahwa perusahaan relatif lebih stabil dan lebih mampu menghasilkan laba dibandingkan perusahaan kecil. Bagi perusahaan yang stabil biasanya tingkat kepastian untuk memperoleh laba sangat tinggi. Sebaliknya, bagi perusahaan kecil besar kemungkinan laba yang diperoleh juga belum stabil karena tingkat kepastian laba lebih rendah. Oleh karena itu, perusahaan besar lebih berpotensi memiliki laba yang persisten dibandingkan dengan perusahaan kecil.

Berdasarkan pecking order theorydalam menghasilkan laba, perusahaan cenderung mengutamakan (mendahulukan) pendanaan dari sumber internal guna membayar deviden dan mendanai investasi, bila kebutuhan dana internal tidak mencukupi maka dipergunakan dana dari sumber eksternal sebagai tambahannya. Pendanaan eksternal dilakukan terutama dengan menerbitkan obligasi (utang) daripada penerbitan saham baru. Dipilihnya penerbitan obligasi lebih utama daripada penerbitan saham baru dikarenakan biaya penerbitan (floatation cost) untuk penerbitan obligasi lebih kecil dibandingkan penerbitan saham baru. Salah satu informasi pada laporan keuangan yang dapat memengaruhi persepsi investor adalah tingkat utang (Kusuma \& Sadjiarto, 2014).

Motif utama perusahaan menggunakan utang yaitu untuk memperbesar tingkat pengembalian (return) dari pemegang saham. Hal ini didasari oleh asumsi bahwa utang dari kreditur dapat diperoleh dengan biaya yang lebih rendah dibandingkan tingkat pengembalian keuntungannya. Hal ini menyebabkan 
manajer berusaha mengurangi fluktuasi laba sehingga risiko pengembalian utangnya menjadi rendah dan dapat meningkatkan kepercayaan kreditur untuk memberikan pinjaman (Enekwe et al., 2014). Manajemen yang memilih utang sebagai alternatif sumber modal dituntut untuk dapat bekerja keras meningkatkan persistensi laba dengan tujuan untuk mempertahankan kinerja perusahaan yang baik di mata auditor dan investor, selain itu agar penggunaan modal tersebut dapat memberikan keuntungan yang besar bagi perusahaan, sehingga perusahaan dapat berkembang dan mampu membayar utang tersebut kepada kreditor. Semakin besarnya tingkat utang maka semakin besar pula perusahaan memperoleh tambahan modal untuk kegiatan usahanya, sehingga laba yang dihasilkan dapat lebih maksimal dan persisten. Investor cenderung akan memiliki pandangan yang lebih baik terhadap perusahaan dengan tingkat utang yang tinggi apabila laba perusahaan tersebut persisten atau sesuai dengan keadaan yang sebenarnya dan berkelanjutan. Pernyataan tersebut sejalan dengan penelitian yang dilakukan oleh Sari dan Fachrurrozie (2016), Yanti (2017) yang menemukan adanya pengaruh positif antara tingkat utang pada persistensi laba. Penelitian Putri dan Supadmi (2016) pada perusahaan manufaktur yang terdaftar di BEI periode 2011-2013 menemukan tingkat utang berpengaruh positif pada pesistensi laba. Hasil yang sama juga ditemukan oleh penelitian Marnilin, dkk. (2015) pada perusahaan jasa dagang dan investasi yang terdaftar di BEI periode 2010-2014.

Berdasarkan kajian teoritis dan empiris tersebut, maka hipotesis penelitian dirumuskan sebagai berikut.

$\mathrm{H}_{1}$ : Tingkat utang berpengaruh positif pada persistensi laba. 
Berdasarkan teori keagenan para agen yang berada pada perusahaan besar akan selalu berupaya meningkatkan kinerjanya agar dinilai baik oleh prinsipal maupun calon investor, karena investor lebih tertarik pada perusahaan berukuran besar. Dengan besarnya ukuran perusahaan maka kinerja agen harus sebaik mungkin untuk membuat laba perusahaan persisten. Persistensi laba perusahaan yang tinggi mengindikasikan hubungan yang semakin kuat antara laba perusahaan dengan imbal hasil bagi investor dalam bentuk return saham (Yin \& Kwon, 2015). Perusahaan besar yang telah mencapai tahap kedewasaan mencerminkan bahwa kondisi perusahaan relatif lebih stabil dan lebih mampu menghasilkan laba dibandingkan perusahaan kecil. Bagi perusahaan yang stabil biasanya tingkat kepastian untuk memperoleh laba sangat tinggi. Sebaliknya, bagi perusahaan kecil besar kemungkinan laba yang diperoleh juga belum stabil karena tingkat kepastian laba lebih rendah. Oleh karena itu, perusahaan besar memiliki laba yang lebih persisten daripada perusahaan kecil. Pernyataan tersebut sejalan dengan penelitian yang dilakukan Anggraeni (2015) dan Vichitsarawong (2015) yang menemukan adanya pengaruh positif ukuran perusahaan pada persistensi laba. Penelitian yang dilakukan oleh Dewi dan Putri (2015) pada perusahaan perhotelan dan pariwisata yang terdaftar di BEI 2009-2011 menunjukkan bahwa ukuran perusahaan berpengaruh positif pada persistensi laba. Hasil yang sama juga ditunjukkan oleh penelitian yang dilakukan oleh Nuraini dan Purwanto (2014) pada perusahaan manufaktur yang terdaftar di BEI periode 2008-2012.

Berdasarkan kajian teoritis dan empiris tersebut maka hipotesis penelitian dirumuskan sebagai berikut. 
$\mathrm{H}_{2}$ : Ukuran perusahaan berpengaruh positif pada persistensi laba.

Berdasarkan teori keagenan adanya perbedaan kepentingan antara manajer (agen) dan pemegang saham (prinsipal) akan menimbulkan konflik (agency conflict) antara keduanya, salah satu cara untuk mengurangi agency conflict adalah dengan adanya kepemilikan saham oleh pihak manajemen perusahaan.Kepemilikan manajerial adalah situasi dimana manajer memiliki saham perusahaan atau dengan kata lain manajer tersebut tidak hanya berperan sebagai agen namun juga bertindak sebagai pemegang saham perusahaan.Hal tersebut akan membuat manajer lebih giat untuk memenuhi keinginan dari pemegang saham yang tidak lain dirinya sendiri. Kepemilikan manajerial dapat digunakan untuk menentukan kualitas laba mendatang yang tercermin dari persistensi labanya, semakin besar pihak manajer memiliki saham perusahaan berarti semakin besar pula rasa tanggung jawab manajer untuk mempertanggung jawabkan laporan keuangan (Jumiati \& Ratnadi, 2014). Peningkatan kepemilikan manajerial akan membawa respon positif bagi pasar. Pasar beranggapan bahwa peningkatan proporsi kepemilikan manajerial menyebabkan manajemen perusahaan akan berupaya meningkatkan persistensi laba untuk memperoleh return saham yang tinggi pula. Pernyataan tersebut sejalan dengan penelitian yang dilakukan oleh Dewata, dkk. (2016) pada perusahaan yang terdaftar dalam Jakarta Islamic Index (JII) di Bursa Efek Indonesia (BEI) periode tahun 2012-2014 menunjukkan bahwa kepemilikan manjerial berpengaruh positif pada persistensi laba. Selain itu penelitian yang dilakukan oleh Khafid (2012), Jumiati dan Ratnadi 
(2014) juga menemukan adanya pengaruh positif kepemilikan manajerial pada persistensi laba.

Berdasarkan kajian teoritis dan empiris tersebut, maka hipotesis penelitian dirumuskan sebagai berikut.

$\mathrm{H}_{3}$ : Kepemilikan manajerial berpengaruh positif pada persistensi laba.

\section{METODE PENELITIAN}

Penelitian ini dilakukan pada perusahaan property dan real estate yang terdaftar di BEI periode 2013-2016. Data dapat diakses melalui website resmi BEI yaitu web.idx.id. Penelitian ini yang menjadi variabel independen adalah tingkat utang $\left(\mathrm{X}_{1}\right)$, ukuran perusahaan $\left(\mathrm{X}_{2}\right)$, dan kepemilikan manajerial $\left(\mathrm{X}_{3}\right)$. Variabel dependen adalah persistensi laba (Y).

Tingkat utang diukur dengan rasio leverage berikut (Putri \& Supadmi, 2016)

Debt Ratio $=\frac{\text { Total Utang }}{\text { Total Aktiva }}$

Ukuran Perusahaan (UP) diukur dengan menggunakan rumus sebagai berikut (Dewi \& Putri, 2015).

$$
\mathrm{UP}=\ln \text { Total Aset }
$$

Kepemilikan Manajerial (KM) diukur dengan menggunakan rumus sebagai berikut (Jumiati \& Ratnadi).

$\mathrm{KM}=\frac{\text { Jumlah saham yang dimiliki pihak manajemen }}{\text { Jumlah saham yang beredar }}$ 
Laba sebelum pajak tahun depan menggunakan skala data rasio dan diukur dengan cara berikut (Suwandika \& Astika, 2013).

$$
\mathrm{PTBI}_{\mathrm{t}}+1=\frac{\text { Laba sebelum pajak tahun depan }}{\text { Rata-rata total aset }}
$$

Laba sebelum pajak tahun berjalan menggunakan skala data rasio dan diukur dengan cara berikut (Jumiati \& Ratnadi, 2014).

$$
\text { PTBIt }=\frac{\text { Laba sebelum pajak tahun berjalan }}{\text { Rata-rata total aset }}
$$

Populasi dari penelitian ini adalah seluruh perusahaan property dan real estate yang terdaftar di BEI periode 2013-2016 sebanyak 48 perusahaan. Teknik sampling yang digunakan dalam penelitian ini adalah teknik non probability sampling. Non probability sampling adalah teknik pengambilan sampel yang tidak memberi peluang atau kesempatan sama bagi setiap unsur atau anggota populasi untuk dipilih menjadi sampel. Teknik non probability sampling yang digunakan dalam pengambilan sampel pada penelitian ini yaitu teknik purposive sampling. Purposive sampling adalah teknik penentuan sampel dengan pertimbangan atau kriteria tertentu.

Langkah pertama yang harus dilakukan dalam penelitian ini adalah menghitung nilai persistensi laba untuk setiap sampel perusahaan dan menguji apakah terdapat peristensi laba dalam data yang diteliti. Pengaruh antara laba tahun berjalan dengan laba tahun depan yang mengindikasikan adanya persistensi laba dapat diketahui apabila hasil regresi variabel tersebut menunjukkan nilai signifikansi kurang dari 0,05 (Cheng et al., 2015). Persistensi laba diukur dengan koefisien regresi sebelum pajak tahun berjalan terhadap laba sebelum pajak tahun 
depan(Suwandika \& Astika, 2013). Regresi ini dilakukan dengan variabel laba sebelum pajak tahun depan $\left(\mathrm{PTBI}_{\mathrm{t}}+1\right)$ sebagai variabel dependen dan variabel laba sebelum pajak tahun berjalan $\left(\mathrm{PTBI}_{\mathrm{t}}\right)$ sebagai variabel independen. Persamaan yang digunakan sebagai berikut.

$\operatorname{PTBI}_{t}+1=\alpha+\beta$ PTBI $_{t}+\varepsilon$

Keterangan:

$\mathrm{PTBI}_{\mathrm{t}}+1$ : laba sebelum pajak tahun depan

PTBI $_{t} \quad$ : laba sebelum pajak tahun berjalan

$\alpha \quad$ : konstanta

$\beta \quad$ : koefisien regresi

$\varepsilon \quad$ :error

\section{HASIL DAN PEMBAHASAN}

Statistik deskriptif dilakukan untuk memberikan informasi mengenai karakteristik variabel-variabel penelitian, yaitu jumlah pengamatan, nilai minimum, nilai maksimum, nilai rata-rata (mean), dan standar deviasi dari masing-masing variabel penelitian, yaitu persistensi laba, tingkat utang, ukuran perusahaan, dan kepemilikan manajerial. Hasil statistik deskriptif dapat dilihat pada Tabel 4.3 sebagai berikut.

Tabel 1.

Statistik Deskriptif Variabel Penelitian

\begin{tabular}{lccccc}
\hline \multicolumn{1}{c}{ Variabel } & $\mathrm{N}$ & Minimum & Maximum & Mean & $\begin{array}{c}\text { Std. } \\
\text { Deviation }\end{array}$ \\
\hline Persistensi Laba $(\mathrm{Y})$ & 44 & 0,0122 & 0,1388 & 0,0665 & 0,0260 \\
Tingkat Utang $\left(\mathrm{X}_{1}\right)$ & 44 & 0,0335 & 0,8362 & 0,4032 & 0,2068 \\
Ukuran Perusahaan $\left(\mathrm{X}_{2}\right)$ & 44 & 25,7727 & 31,0008 & 28,8085 & 1,4791 \\
Kepemilikan Manajerial $\left(\mathrm{X}_{3}\right)$ & 44 & 0,0000 & 0,7400 & 0,1281 & 0,2296 \\
Valid N (listwise) & 44 & & & & \\
\hline
\end{tabular}

Sumber: Data diolah, 2018

Hasil analisis deskriptif pada Tabel 1 menunjukkan nilai minimum variabel persistensi laba (Y) sebesar 0,0122 yang dimiliki oleh PT Ristia Bintang 
Mahkota Sejati Tbk artinya persistensi laba minimum perusahaan property dan real estate selama tahun 2013 sampai 2016 sebesar adalah 0,0122. Nilai maksimum variabel persistensi laba adalah sebesar 0,1388 yang dimiliki oleh PT Greenwood Sejahtera Tbk artinya persistensi laba maksimum perusahaan property dan real estate selama tahun 2013 sampai 2016 adalah sebesar 0,1388. Nilai ratarata hitung (mean) variabel persistensi labasebesar 0,0665. Nilai rata-rata persistensi laba lebih mendekati nilai minimum, hal ini berarti rata-rata persistensi pada perusahaan property dan real estate periode 2013-2016 cenderung rendah. Nilai standar deviasi sebesar 0,0260 lebih kecil dari nilai rata-rata artinya terdapat fluktuasi yang rendah pada persistensi laba di perusahaan yang menjadi sampel.

Variabel tingkat utang $\left(\mathrm{X}_{1}\right)$ memiliki nilai minimum sebesar 0,0335 yang dimiliki oleh PT Ristia Bintang Mahkota Sejati Tbk artinya tingkat utang minimum perusahaan property dan real estate selama tahun 2013 sampai 2016 sebesar adalah 0,0335. Nilai maksimum variabel tingkat utang adalah sebesar 0,8362 yang dimiliki oleh PT Binakarya Jaya Abadi Tbk artinya tingkat utang maksimum perusahaan property dan real estate selama tahun 2013 sampai 2016 adalah sebesar 0,8362. Nilai rata-rata hitung (mean) variabel tingkat utangsebesar 0,4032. Nilai rata-rata tingkat utang lebih mendekati nilai minimum, hal ini berarti rata-rata tingkat utang pada perusahaan property dan real estate periode 2013-2016 cenderung rendah. Nilai standar deviasi sebesar 0,0268 lebih kecil dari nilai rata-rata artinya terdapat fluktuasi yang rendah pada tingkat utang di perusahaan yang menjadi sampel. 
Ni Nyoman Dita Arisandi dan Ida Bagus Putra Pastika. Pengaruh ...

Variabel ukuran perusahaan $\left(\mathrm{X}_{2}\right)$ memiliki nilai minimum sebesar 25,7727 yang dimiliki oleh PT Ristia Bintang Mahkota Sejati Tbk artinya ukuran perusahaan minimum perusahaan property dan real estate selama tahun 2013 sampai 2016 sebesar adalah 25,7727. Nilai maksimum variabel ukuran perusahaan adalah sebesar 31,0008 yang dimiliki oleh PT Ciputra Development Tbk artinya ukuran perusahaan maksimum perusahaan property dan real estate selama tahun 2013 sampai 2016 adalah sebesar 31,0008. Nilai rata-rata hitung (mean) variabel ukuran perusahaan sebesar 28,8085. Nilai rata-rata ukuran perusahaan lebih mendekati nilai maksimum, hal ini berarti rata-rata ukuran perusahaan pada perusahaan property dan real estate periode 2013-2016 cenderung besar. Nilai standar deviasi sebesar 1,4791 lebih kecil dari nilai ratarata artinya terdapat fluktuasi yang rendah pada ukuran perusahaan di perusahaan yang menjadi sampel.

Variabel kepemilikan manajerial $\left(\mathrm{X}_{3}\right)$ memiliki nilai minimum sebesar 0,0000 yang dimiliki oleh PT Intiland Development Tbk artinya kepemilikan manajerial minimum perusahaan property dan real estate selama tahun 2013 sampai 2016 sebesar adalah 0,0000. Nilai maksimum variabel kepemilikan manajerial adalah sebesar 0,7400 yang dimiliki oleh PT Binakarya Jaya Abadi Tbk artinya kepemilikan manajerial maksimum perusahaan property dan real estate selama tahun 2013 sampai 2016 adalah sebesar 0,7400. Nilai rata-rata hitung (mean) variabel ukuran perusahaan sebesar 0,1281. Nilai rata-rata kepemilikan manajerial lebih mendekati nilai minimum, hal ini berarti rata-rata kepemilikan manajerial pada perusahaan property dan real estate periode 2013- 
2016 cenderung rendah. Nilai standar deviasi sebesar 0,2296 lebih besar dari nilai rata-rata, artinya terdapat fluktuasi yang tinggi pada kepemilikan manajerial di perusahaan yang menjadi sampel.

Analisis regresi sederhana dalam penelitian ini dilakukan untuk menghitung dan mengetahui adanya persistensi laba pada data yang digunakan dalam penelitian ini. Regresi ini dilakukan dengan variabel laba sebelum pajak tahun depan (PTBIt+1) sebagai variabel dependen dan variabel laba sebelum pajak tahun berjalan (PTBIt) sebagai variabel independen. Pengaruh antara laba tahun berjalan dengan laba tahun depan yang mengindikasikan adanya persistensi laba dapat ditunjukkan dengan apabila hasil regresi variabel tersebut menunjukkan nilai signifikansi kurang dari 0,05. Hal ini menunjukkan kesinambungan laba, maka dari itu apabila laba tahun berjalan berpengaruh pada laba tahun depan maka laba tersebut dapat dikatakan persisten. Hasil regresi antara laba sebelum pajak tahun berjalan (PTBIt) dengan laba sebelum pajak tahun depan (PTBIt+1) dapat dilihat pada Tabel 2 berikut

Tabel 2.

\section{Analisis Regresi Sederhana}

\begin{tabular}{lccccc}
\hline Model & \multicolumn{2}{c}{$\begin{array}{c}\text { Unstandardized } \\
\text { Coefficients }\end{array}$} & $\begin{array}{c}\text { Standardized } \\
\text { Coefficients }\end{array}$ & $\mathrm{t}$ & Sig. \\
& $\mathrm{B}$ & Std. Error & Beta & & \\
\hline (Constant) $_{\text {PTBI }}$ & 0,041 & 0,010 & & 3,978 & 0,000 \\
\hline Sumber & 0,350 & 0,086 & 0,471 & 4,071 & 0,000 \\
\hline
\end{tabular}

Sumber: Data diolah, 2018

Berdasarkan hasil analisis regresi sederhana pada Tabel 2 dapat dibuat persamaan sebagai berikut.

$$
\mathrm{PTBI}_{\mathrm{t}}+1=0,041+0,350 \mathrm{PTBI}_{\mathrm{t}}
$$


Persamaan regresi di atas digunakan unutk mengukur nilai persistensi laba pada masing-masing perusahaan yang digunakan sebagai sampel dalam penelitian ini. Selain itu, pada hasil analisis regresi sederhana di atas menunjukkan nilai signifikansi sebesar 0,000 lebih kecil dari 0,05. Hal ini berarti terdapat pengaruh signifikan antara laba sebelum pajak tahun berjalan $\left(\mathrm{PBTI}_{\mathrm{t}}\right)$ dengan laba sebelum pajak tahun depan $\left(\mathrm{PTBI}_{\mathrm{t}}+1\right)$. Maka dari itu, dapat disimpulkan bahwa dalam sampel perusahaan property dan real estate dalam penelitian ini terdapat persistensi laba.

Analisis regresi linear berganda dilakukan untuk mengetahui pengaruh antara variabel bebas pada variabel terikat. Dalam penelitian ini analisis regresi linear berganda digunakan untuk mengetahui besarnya pengaruh tingkat utang, ukuran perusahaan, dan kepemilikan manajerial pada prsistensi labaperusahaan property dan real estate yang terdaftar di BEI periode 2013-2016. Hasil analisis regresi linier berganda dapat dilihat pada Tabel 3 berikut.

Tabel 3.

Analisis Regresi Linier Berganda

\begin{tabular}{lccc}
\hline \multicolumn{1}{c}{ Variabel } & \multicolumn{2}{c}{ Unstandardized Coefficients } & Sig. \\
& $\mathrm{B}$ & Std. Error & \\
\hline (Constant) & $-0,205$ & 0,125 & 0,108 \\
Tingkat Utang $\left(\mathrm{X}_{1}\right)$ & $-0,022$ & 0,028 & 0,429 \\
Ukuran Perusahaan $\left(\mathrm{X}_{2}\right)$ & 0,010 & 0,005 & 0,038 \\
Kepemilikan Manajerial $\left(\mathrm{X}_{3}\right)$ & 0,008 & 0,026 & 0,760 \\
& & & \\
Adjusted R Square & 0,137 & & \\
F & 3,274 & & \\
F Sig. & 0,031 & & \\
\hline
\end{tabular}

Sumber: Data diolah, 2018

Berdasarkan hasil analisis regresi linier berganda pada Tabel 3 dapat dibuat persamaan sebagai berikut.

$$
Y=-0,205-0,022 X_{1}+0,010 X_{2}+0,008 X_{3}
$$


Persamaan di atas menunjukkan bahwa konstanta sebesar -0,205 memiliki arti apabila tingkat utang, ukuran perusahaan, dan kepemilikan manajerial sama dengan 0 maka nilai persistensi laba sama dengan $-0,205$. Nilai koefisien regresi tingkat utang sebesar -0,022 mempunyai arti bahwa apabila nilai variabel tingkat utang naik 1 satuan maka menyebabkan persistensi laba menurun sebesar 0,022 satuan dengan asumsi variabel lainnya konstan. Nilai koefisien regresi ukuran perusahaan sebesar 0,010 mempunyai arti bahwa apabila nilai variabel ukuran perusahaan naik 1 satuan maka menyebabkan persistensi laba meningkat sebesar 0,010 satuan dengan asumsi variabel lainnya konstan. Nilai koefisien kepemilikan manajerial sebesar 0,008 mempunyai arti bahwa apabila nilai variabel kepemilikan manajerial naik 1 satuan maka menyebabkan persistensi laba meningkat sebesar 0,008 satuan dengan asumsi variabel lainnya konstan.

Berdasarkan Tabel 3 menunjukkan nilai koefisien determinasi sebesar 0,137 yang berarti 13,7\% variasi variabel persistensi laba dapat dijelaskan oleh variasi variabel tingkat utang, ukuran perusahaan, dan kepemilikan manajerial, sedangkan sisanya sebesar $86,3 \%$ dapat dijelaskan oleh variabel-variabel lain di luar model penelitian.

Berdasarkan Tabel 3 dapat dilihat nilai $\mathrm{F}$ hitung sebesar 3,274 dengan tingkat signifikansi sebesar 0,031 lebih kecil dari 0,05. Berdasarkan hasil tersebut maka dapat disimpulkan bahwa model penelitian ini dikatakan layak untuk diteliti dan dapat dilanjutkan dengan pembuktian hipotesis.

Berdasarkan Tabel 3 variabel tingkat utang memiliki hasil koefesien tingkat utang sebesar -0,022 dengan nilai signifikansi 0,429 lebih besar dari 0,05 
maka $\mathrm{H}_{1}$ ditolak yang menjelaskan bahwa tingkat utang tidak berpengaruh pada persistensi laba. Hal ini menunjukkan semakin rendah maupun semakin tinggi tingkat utang yang digunakan oleh perusahaan, tidak memengaruhi kenaikan maupun penurunan persistensi laba.

Tingkat utang tidak berpengaruh pada persistensi pada penelitian ini terjadi karena kinerja perekonomian global yang mengalami stagnasi beberapa tahun belakang akibat dari melemahnya mata uang rupiah yang telah memengaruhi perekonomian Indonesia, khususnya pendapatan ekspor, investasi, pendapatan negara serta daya beli masyarakat. Terlebih lagi sektor industri property dan real estate yang paling rentan terkena imbas dari anjloknya rupiah karena bahan konstruksi yang digunakan untuk pembangunan berasal dari impor. Hal tersebut membuat harga property melambung sehingga berdampak pada menurunnya daya beli masyarakat. Oleh karena itu tinggi rendahnya tingkat utang perusahaan yang digunakan untuk kegiatan produksi tidak memengaruhi laba perusahaan karena lemahnya daya beli masyarakat. Selain itu, tingkat utang tidak berpengaruh pada laba perusahaan juga bisa terjadi karena utang tersebut oleh perusahaan digunakan untuk membiayai ekspansi (perluasan perusahaan), karena dana yang diperlukan perusahaan untuk kebutuhan tersebut cukup besar dan memerlukan waktu yang cukup panjang sampai modal yang digunakan untuk ekspansi tersebut menghasilkan keuntungan.Hasil penelitian ini mendukung penelitian yang dilakukan oleh Suwandika dan Astika (2013), Nurochman dan Solikhah (2015), Barus dan Rica (2014), Nuraini dan Purwanto (2014) serta 
Sulastri (2014) yang menemukan bahwa tingkat utang tidak berpengaruh pada persistensi laba.

Berdasarkan Tabel 3 variabel ukuran perusahaan memiliki hasil koefesien ukuran perusahaan sebesar 0,010 dengan nilai signifikansi 0,038 lebih kecil dari 0,05 maka $\mathrm{H}_{2}$ diterima yang menjelaskan bahwa ukuran perusahaan berpengaruh positif pada persistensi laba. Hal ini menunjukkan bahwa semakin besar ukuran perusahaan maka semakin besar pula persistensi laba perusahaan tersebut dan sebaliknya, dengan asumsi bahwa variabel lain konstan.

Hasil ini mendukung teori keagenan yang menyatakan bahwapara agen yang berada pada perusahaan besar akan selalu berupaya meningkatkan kinerjanya agar dinilai baik oleh prinsipal maupun calon investor. Investor lebih tertarik pada perusahaan berukuran besar, karena dengan besarnya ukuran perusahaan maka kinerja agen harus sebaik mungkin untuk membuat laba perusahaan persisten. Persistensi laba perusahaan yang tinggi mengindikasikan hubungan yang semakin kuat antara laba perusahaan dengan imbal hasil bagi investor dalam bentuk return saham.

Perusahaan besar akan lebih memiliki tingkat persistensi laba yang lebih tinggi daripada perusahaan kecil. Perusahaan besar cenderung mendapat perhatian lebih dari masyarakat luas. Oleh karena itu, biasanya perusahaan besar memiliki kecenderungan untuk selalu menjaga stabilitas dan kondisi perusahaan. Untuk menjaga stabilitas dan kondisi ini, perusahaan tentu saja akan berusaha untuk mempertahankan dan terus meningkatkan kinerja yang pada akhirnya akan berpengaruh terhadap laba yang dihasilkan. Upaya untuk mempertahankan dan 
Ni Nyoman Dita Arisandi dan Ida Bagus Putra Pastika. Pengaruh ...

meningkatkan kinerja tersebut menjadikan perusahaan mampu untuk mempertahankan jumlah laba yang diperoleh saat ini sampai masa yang akan datang sehingga laba tersebut tergolong persisten. Hasil penelitian ini juga mendukung penelitian dari Anggraeni (2015), Vichitsarawong (2015), Dewi dan Putri (2015) serta Nuraini dan Purwanto (2014) yang menemukan bahwa ukuran perusahaan berpengaruh positif pada persistensi laba.

Berdasarkan Tabel 3variabel kepemilikan manajerial memiliki hasil koefesien kepemilikan manajerial sebesar 0,008 dengan nilai signifikansi 0,760 lebih besar dari 0,05 maka $\mathrm{H}_{3}$ ditolak yang menjelaskan bahwa kepemilikan manajerial tidak berpengaruh pada persistensi laba. Hal ini menunjukkan semakin rendah maupun semakin tinggi kepemilikan manajerial yang dimiliki oleh perusahaan, tidak memengaruhi kenaikan maupun penurunan persistensi laba.

Kepemilikan manajerial tidak berpengaruh pada persistensi laba dikarenakan kepemilikan manajerial pada perusahaan property dan real estate yang terdaftar di BEI periode 2013-2016 masih jarang ditemui. Hal ini dapat diamati dari jumlah perusahaan property dan real estate yang terdaftar di BEI selama periode 2013-2016 sebanyak 48 perusahaan namun hanya 15 perusahaan yang memiliki saham manajerial. Selain itu dari hasil statistik deskriptif dapat dilihat bahwa nilai rata-rata kepemilikan manajerial lebih mendekati nilai minimum, hal ini berarti rata-rata kepemilikan manajerial pada sampel penelitian ini cenderung rendah. Kepemilikan saham manajerial di setiap tahunnya mayoritas tidak mengalami kenaikan, hanya PT Binakarya Jaya Abadi Tbk yang mengalami sedikit fluktuasi pada saham manajerial. Tidak adanya kenaikan 
saham manajemen dan jumlah saham beredar membuat keputusan yang diambil pihak manajerial tidak berpengaruh pada laba perusahaan. Hasil penelitian ini mendukung teori keagenan bahwa rendahnya tingkat kepemilikan saham manajerial mengakibatkan pihak manajer merasa kurang memiliki kepentingan yang sama dengan pemegang saham yaitu memperoleh dividen yang tinggi dari laba perusahaan dengan persistensi yang tinggi. Manajer kurang termotivasi untuk meningkatkan kinerja perusahaan sehingga tidak memengaruhi persistensi laba perusahaan. Hasil penelitian ini juga mendukung penelitian dari Nuraeni, dkk. (2018), Yushita, dkk. (2013), Riswadi (2014), serta Putri dan Supadmi (2016) yang menemukan bahwa kepemilikan manajerial tidak berpengaruh pada persistensi laba.

\section{SIMPULAN}

Berdasarkan hasil regresi sederhana nilai signifikansi dari variabel persistensi laba sebesar 0,000 lebih kecil dari 0,05 sehingga dapat disimpulkan perusahaan property dan real estate yang digunakan sebagai sampel dalam penelitian ini terdapat persistensi laba.Variabel tingkat utangtidak berpengaruh pada persistensi laba di perusahaan property dan real estate yang terdaftar di BEI periode 20132016. Variabel ukuran perusahaan berpengaruh positif pada persistensi laba di perusahaan property dan real estate yang terdaftar di BEI periode 2013-2016. Variabel kepemilikan manajerial tidak berpengaruh pada persistensi laba di perusahaan property dan real estate yang terdaftar di BEI periode 2013-2016. 
Nilai koefisien determinasi masih cukup rendah yaitu sebesar 0,137 atau $13,7 \%$. Hal tersebut menunjukkan bahwa masih banyak faktor lain yang dapat mempengaruhi persistensi laba. Penelitian selanjutnya diharapkan dapat menambahkan beberapa variabel bebas dan variabel moderasi.

Hasil penelitian ini menunjukkan tingkat utang tidak berpengaruh pada persistensi laba dan memiliki nilai koefisien regresi yang berarah negatif. Maka dari itu, disarankan bagi pihak manajemen yang menggunakan pendanaan dari utang untuk kegiatan operasional perusahaan agar penggunaan utang tersebut berpedoman pada trade off theory dimana apabila manfaat lebih kecil daripada pengorbanan dari yang dikeluarkan untuk utang tersebut, maka porsi penggunaan utang oleh perusahaan tersebut sudah tidak dapat ditambah agar tidak menimbulkan risiko gagal bayar. Sedangkan apabila manfaat dari penggunaan utang tersebut lebih besar dari pada pengorbanan yang dikeluarkan, maka porsi penggunaan utang pada perusahaan tersebut masih diperbolehkan untuk ditambah karena pihak manajemen mampu mengelola utang tersebut sehingga menghasilkan laba yang tinggi.

Hasil penelitian ini menunjukkan ukuran perusahaan berpengaruh positif pada persistensi laba. Maka dari itu, bagi pihak investor dan kreditodisarankan sebelum mengambil keputusan untuk berinvestasi dan memberikan pinjaman agar memerhatikan skala besar kecilnya perusahaan tersebut yang dapat dilihat dari total aset pada laporan keuangan perusahaan tersebut karena berdasarkan hasil penelitian ini semakin besar ukuran perusahaan terbukti akan semakin meningkatkan persistensi laba perusahaan sehingga dividen yang dibagikan 
kepada pemegang saham juga akan semakin tinggi dan perusahaan akan mampu melunasi utang yang telah jatuh tempo.

Hasil penelitian ini menunjukkan kepemilikan manajerial tidak berpengaruh pada persistensi laba karena rendahnya kepemilikan manajerial. Maka dari itu disarankan bagi perusahaan agar menerapkan program Employee Stock Ownership Program (ESOP). Salah satu fungsi ESOP adalah menunjang terjadinya Good Corporate Governance (GCG). Hal ini dikarenakan terdapat salah satu mekanisme dalam GCG yaitu kepemilikan manajerial, dan ESOP adalah salah satu bentuk dari kepemilikan manajerial (Wikrami, 2016). Ini akan berdampak pada karyawan tidak melihat lagi laba yang diperoleh perusahaan namun juga bagaimana citra perusahaan di mata publik.

Penelitian selanjutnya juga diharapkan dapat menambahkan periode pengamatan dan tidak hanya meneliti persistensi laba pada perusahaan property dan real estate namun dapat memperluas sampel perusahaan seperti seluruh perusahaan yang terdaftar di BEI. Jangka waktu yang diperpanjang dan penambahan jumlah sampel mungkin akan memberikan hasil yang lebih baik dalam penelitian.

\section{REFERENSI}

Achyarsyah, P. \& Purwanti, A. J. (2018). Pengaruh Perbedaan Laba Komersial dan Laba Fiskal, Pajak Tangguhan, dan Leverage Terhadap Persistensi Laba. Jurnal Ilmu Akuntansi, 16(2), 56-67.

Ali, A. M., Al-Shattarat, \& Yusuf, A. N. (2015). The Effects of Contextual Factors on Disaggregated Earnings in Explaining Dividend Changes in Jordanian Firms. International Journal of Commerce and Management. 25(2), 218-239. https:// doi.org/ 10.1108/IJCoMA-02-2013-0016 
Anggraeni, B. M. (2015). Analisis Faktor-Faktor yang Memengaruhi Persistensi Laba. Jurnal Ilmiah Universitas Bakrie, 3(3), 1-2.

Barus, A., C., \& Rica, V. (2014). Analisis Faktor-Faktor yang Mempengaruhi Kualitas Laba Pada Perusahaan Manufaktur di Bursa Efek Indonesia. Jurnal Wira Ekonomi Mikroskil, 4(2), 71-80.

Cheng, C. H., Hsieh. C. C., \& Wang, J. S. (2015). Earnings Volatility, Accounting Conservatism, and Earnings Persistence: A Consideration of Unsystematic Earnings and Systematic Earnings Components. International Research Journal of Applied Finance, 6(3), 186-196.

Dewata, E., Sari, Y. \& Fithri, E. J. (2016.) Kepemilikan Manajerial dan Kepemilikan Institusional Sebagai Determinan Struktur Modal Dan Persistensi Laba. Jurnal Riset dan Akuntansi: Akuntansi dan Manajemen, 1(3), 73-84.

Dewi, L., \& Putri, D. (2015). Pengaruh Book-Tax Difference, Arus Kas Operasi, Arus Kas Akrual, dan Ukuran Perusahaan Pada Persistensi Laba. E-Jurnal Akuntansi Universitas Udayana, 10(1), 244-260. https://dx.doi.org/10.1016/j.jacceco.2015.06.003

Enekwe, C. I., Agu, C. I., \& Nnagbogu, E. K. (2014). The Effect of Financial Leverage on Financial Performance: Evidence of Quoted Pharmaceutical Companies in Nigeria. IOSR Journal of Economics and Finance, 5(3), 17-25.

Gschwandtner, A., \& Cuaresma, J. C. (2013). Explaining The Persistence of Profits: A Time-Varying Approach Explaining The Persistence of Profits. International Journal of the Economics of Business, 20(1), 37-41. http://dx.doi.org/10.1016/j.jacceco.2015.06.003

Hartomo, Giri. (2018). Rupiah Anjlok Rp14.084/USD, Sektor Properti Kena Imbasnya. Diunduh dari Okezone Finance website: https://economy.okezone.com/read/2018/05/09/470/1896465/rupiah-anjlokrp14-084-usd-sektor-properti-kena-imbasnya

Hui, K. W., Nelson, K. K., \& Yeung, P. E. (2016). On The Persistence and Pricing of Industry-Wide and Firm-Specific Earnings, Cash Flows, and Accruals. Journal of Accounting and Economics, 61(1), 185-202. http://dx.doi.org/10.1016/j.jacceco.2015.06.003

Jensen, M \& Meckling, W. (1976). Theory of The Firm: Managerial Behavior, Agency Costs and Ownership Structure. Journal of Financial and Economics, 3(4), 305-360. 
Jumiati, F., \& Ratnadi, D. (2014). Pengaruh Kepemilikan Manajerial dan Book Tax Differences Pada Persistensi Laba. E-Jurnal Akuntansi Universitas Udayana, 8(2), 91-101.

Khafid, M. (2012). Pengaruh Tata Kelola Perusahaan (Corporate Governance) dan Struktur Kepemilikan Terhadap Persistensi Laba. Jurnal Dinamika Akuntansi, 4(2), 139-148.

Kolozsvari, A. C. (2016). Analysis of The Influence of Income Smoothing Over Earnings Persistence in The Brazilian Market*. R. Cont. Fin. - USP, São Paulo, 27(72), 306-319. https://doi.org/10.1590/1808-057x201602610

Kordestani, G., Taqiporian, M., Biglari, V., \& Minaei, V. (2016). Persistence of Earnings and Prediction of Future Cash Flows: The Role of Timely Recognition of Bad News. Business: Theory and Practice, 17(4), 353-360. https://doi.org/10.3846/btp.17.11124

Kusuma, B., \& Sadjiarto, R. A. (2014). Analisa Pengaruh Volatilitas Arus Kas, Volatilitas Penjualan, Tingkat Hutang, Book Tax Gap, dan Tata Kelola Perusahaan Terhadap Persistensi Laba. Tax \& Accounting Review,4(1), 1-8.

Marnilin, F., Mulyadi, J., \& Darmansyah. (2015). Analisis Determinan Terhadap Persistensi Laba Pada Perusahaan Jasa di BEI. Media Riset Akuntansi, Auditing \& Informasi, 15(1), 89-102.

Martinez, A. L., Tatiana, B. T. S., \& Danilo, S. M. (2015). Book-Tax Differences, Earnings Persistence and Tax Planning Before and After The Adoption of IFRS in Brazil. Advances in Scientific and Aplied Accounting Journal, 9(6), $1-18$.

Moienadin, M., \& Tabatabaenasab, Z. (2014). Examining The Earnings Persistence and Its Components In Explaining The Future Future Profitability. Interdisciplinary Journal of Contemporary Research In Business February, 5(10), 104-117.

Nuraeni, R., Mulyati, S., \& Putri, T. E. (2018). Faktor-Faktor yang Mempengaruhi Persistensi Laba (Studi Kasus Pada Perusahaan Property dan Real Estate yang Terdaftar di Bursa Efek Indonesia Tahun 2013-2015). Accruals (Accounting Reserach Journal of Sutaatmadja, 1(1), 82-112.

Nuraini, M., \& Purwanto, A. (2014). Analisis Faktor-Faktor Penentu Persistensi Laba. Diponegoro Journal Of Accounting, 3(3), 2337-3806.

Nurochman, A., \& Solikhah, B. (2015). Pengaruh Good Corporate Governance, Tingkat Hutang dan Ukuran Perusahaan Terhadap Persistensi Laba. Accounting Analysis Journal, 1(2), 1-6. 
Putri, G., \& Supadmi, N. L. (2016). Pengaruh Tingkat Hutang dan Kepemilikan Manajerial Terhadap Persistensi Laba Pada Perusahaan Manufaktur. EJurnal Akuntansi Universitas Udayana, 15(2), 915-942.

Riswandi, Pedi. (2014). Pengaruh Kepemilikan Manajerial, Proporsi Komisaris Independen Terhadap Kualitas Laba. Jurnal Ekombis Riview, 2(2), 210-223.

Sari, S. P., \& Fachrurrozie. (2016). The Analysis of Factors and Moderation of Book Tax Difference On The Property Real Estate. Accounting Analysis Journal, 5(3), 182-188

Sujana, M., Yasa, G. W., \& Badera, I. D. N. (2017). Pengaruh Komite Audit dan Kepemilikan Institusional Pada Persistensi Laba Perusahaan Manufaktur. EJurnal Ekonomi dan Bisnis Universitas Udayana, 6(12), 4311-4338

Sulastri, D. A. (2014). Pengaruh Volatilitas Arus Kas dan Tingkat Hutang Terhadap Persistensi Laba. E-Journal UNP, 2(2), 1-29.

Sutisna, H. (2017). Accruals and Cash Flow Volatility of The Earnings Persistence. International Journal of Economic Perspectives, 11(1), 15581570.

Suwandika, I. M. A., \& Astika, I. B. P. (2013). Pengaruh Perbedaan Laba Akuntansi, Laba Fiskal, Tingkat Hutang Pada Persistensi Laba. E-Jurnal Akuntansi Universitas Udayana, 5(1), 196-214.

Tertius, M. A., \& Christiawan Y. J. (2015). Pengaruh Good Corporate Governance Terhadap Kinerja Perusahaan Pada Sektor Keuangan. Business Accounting Review, 3(1),223-232.

Vichitsarawong, T., \& Sompong, P. (2015). Do Audit Opinions Reflect Earnings Persistence?. Managerial Auditing Journal, 30(3), 244-276. https:// doi.org/10.1108/MAJ-12-2013-0973

Wikrami, I. A. P. (2016). Pengaruh Manajemen Laba Pada Harga Eksekusi ESOP Dengan Good Corporate Governance Sebagai Variabel Moderating. EJurnal Akuntansi Universitas Udayana, 16(1), 416-443.

Yanti, Y. (2017). The Effects of Operating Cash Flow, Sales Volatility, and Leverage On Earnings. International Journal of Economic Perspectives, 11(1), 1535-1544.

Yosra, B. M. (2015). Earnings Volatility and Earnings Predictability. Journal of Business Studies Quarterly, 6(3), 37-53. 
Yushita, A. N., Triatmoko, H., \& Rahmawati. (2013). Pengaruh Mekanisme Corporate Governance, Kualits Auditor Eksternal, dan Likuiditas Terhadap Kualitas Laba. Jurnal Economia, 9(2), 141-155.

Zhou, M. (2016). Does Accounting For Uncertain Tax Benefits Provide Information About The Relation Between Book-Tax Differences and Earnings Persistence?. Review of Accounting and Finance, 15(1), 65-84. https:// doi.org/10.1108/RAF-05-2014-0054 